\author{
AUTHORS: \\ Dr Benedicta A. Ajibade ${ }^{1}$ \\ Prof Carol Bertram ${ }^{1}$ iD \\ AFFILIATION: \\ ${ }^{1}$ School of Education, University \\ of KwaZulu-Natal, South Africa \\ E-MAIL: \\ bennyajibade@gmail.com
}

DOI: http://dx.doi.

org/10.18820/2519593X/pie.v38.

i2.07

e-ISSN 2519-593X

Perspectives in Education

2020 38(2): 103-117

PUBLISHED:

04 December 2020
Published by the UFS

http://journals.ufs.ac.za/index.php/pie

(-) Creative Commons

With Attribution (CC-BY)

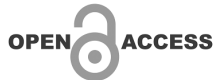

\section{HOW DISTRICT TEACHER DEVELOPMENT CENTRES SUPPORT TEACHERS' \\ LEARNING: CASE STUDIES IN KWAZULU-NATAL, SOUTH AFRICA}

\begin{abstract}
This research is based on case studies of seven district teacher development centres (DTDCs) in the KwaZulu-Natal province of South Africa. The paper describes the perceptions of selected teachers regarding professional learning and development experiences at these centres. The purpose of the study was to determine the role centres play in supporting teachers' learning and development as stipulated in the Integrated Strategic Planning Framework for Teacher Education and Development (ISPFTED) policy in South Africa. The study employed a qualitative research approach in which semi-structured interviews, observation, document analysis and field notes were used to generate data from six centre managers, two librarians, two ICT specialists and 46 teachers at the centres. Findings from the study indicated that the DTDCs create an ideal opportunity for teachers' professional learning with the presence of computer, science laboratories and libraries. However, the study noted that teachers seldom used these resources. Teachers used the centres mainly for professional development activities such as workshops and meetings. Our study concludes that at present, the centres are not supporting the full vision of the policy, and the potential of DTDCs to enhance teacher learning and development remains largely untapped.
\end{abstract}

Keywords: District teacher development centre, teacher learning, professional development policy, managerial professionalism

\section{INTRODUCTION}

An education system cannot be better than its teachers; thus, teacher development is a key focus of many systems. In South Africa, a range of policies had been implemented to support and align teacher development practices. The most recent policy is the Integrated Strategic Planning Framework for Teacher Education and Development (ISPFTED) 2011-2025. The plan expresses the seriousness with which the Department of Education views current educational challenges. One of the requirements stated in this framework is that provincial education departments 
need to establish district teacher development centres (DTDCs) to serve as local support sites for teachers (DBE \& DHET, 2011).

DTDCs have been established as part of school improvement efforts and provide access to resources, sites for curriculum delivery and continuous professional development training as well as a meeting place for professional learning communities (DBE \& DHET, 2011). While the idea of DTDCs is laudable, the extent to which this vision has been realised is not clear. One cannot make a case for the success of the DTDCs without asking the following questions: What kind of professional development activities are delivered at these centres? How are the professional learning communities organised and monitored? Are there enough personnel to run the DTDCs? Accordingly, this study aimed to understand the extent to which these DTDCs support teachers' learning and development in KwaZulu-Natal.

\section{BACKGROUND}

\section{The Plan policy and the establishment of DTDCs in South Africa}

Research studies on teacher professional development and teacher quality have been identified as a lever for improving the quality of teaching and student outcomes (Bayar, 2014; Borko et al., 2010; Higgins \& Parson, 2011; Klieger \& Oster-Levinz, 2015; Van der Bergh et al., 2015). Unfortunately, research in South Africa and internationally has shown that professional development approaches intended to help teachers move beyond typical teaching practices have not had a significant impact on teaching and learning (Bantwini, 2012; Bertram, 2011; Luneta, 2012; Jita \& Mokhele, 2014; Opfer \& Pedder, 2011). Nonetheless, Bautista et al. (2015) identified features related to the content and design of professional development programmes for teachers that are regarded as "features of high-quality PD". Thus, it is important to ascertain the basic mechanisms for the effectiveness of these programmes (Bautista, Wong \& Gopinathan, 2015).

Teacher development has been part of the central focus of South African education reform and development initiatives. In July 2009, a teacher development summit was held to address the challenges facing teacher education in the country. Hence, ISPFTED (2011-2025) (known as the Plan) was developed, which paved the way for the establishment of district teacher development centres (DTDCs). DTDCs are therefore a conscious effort to boost educational support and address the challenges facing teachers, especially those working in rural areas where learners' educational attainment is low and teachers do not have easy access to resources and professional development opportunities (DBE, 2011; Van der Berg et al., 2011). Similarly, Bantwini (2018) argues that the lack of attention to education quality and failure to reach the marginalised members of the society have immensely affected teaching and learning, which can no longer be overlooked. Thus, supporting teachers to meet these expanded challenges through their involvement in DTDCs is essential. To date, 147 fullservice DTDCs have been established across all the provinces (DBE, 2011).

\section{Studies on teacher development centres in other contexts}

The concept of teacher development centre is termed differently in various contexts. According to Giordano (2008), this model has been widely promoted across countries under different names such as teacher resource centres, teacher activity centres, teacher advisory centres and teacher support groups (Giordano, 2008). Teacher resource centres (TRCs) started in Britain in the 1960s as a strategy for delivering a range of educational resources 
and supporting teachers' professional development (Fairhurst et al., 1999). The ideal of TRC initiatives spread to other countries as part of national education reforms (Giordano, 2008). According to Fairhurst et al. (1999:24), TRCs are "places where teachers from several surrounding schools could meet and discuss with one another, work on curricula, develop materials, but most importantly, develop their knowledge and skills".

Research carried out in Tanzania by Mosha (2015) points out the importance of TRCs as an independent environment where teachers can access organised educational resources, get assistance and have productive discussions with their colleagues. Sabaya (2011 cited in Mosha, 2015) indicates that TRCs provide opportunities for teachers to obtain necessary professional support for day-to-day work. Various studies on TRCs in Britain have shown that the teachers who visited these centres were relatively well trained, very well resourced and had a high level of autonomy in terms of curriculum and classroom practice (Weindling et al., 1983). However, research shows that very little systematic curriculum development was in operation and only small groups of teachers and head teachers engaged in such activities at the centres. Hence, the authors concluded that materials production and curriculum development were difficult tasks for teachers to achieve in the limited sessions at the TRCs (Weindling et al., 1983).

Similarly, empirical research conducted in India and Zambia shows that while teachers were supposed to reflect on practice, exchange experiences and develop materials, the centres failed to support these ideas (Fairhurst et al., 1999). Noticeably, in India, where meetings are rigidly structured, the centres lacked formative opportunities for professional development activities and skilled personnel. In Zambia, the only strategy identified that gives teachers opportunity to think about teaching was the newly established school-based teacher workshop programme. However, with little resources, it was not enough to bring about change in their practice (Fairhurst et al., 1999).

In Kenya, it was found that centres provided ongoing workshop support for teachers on exams, syllabi and provided essential resources. However, it was noted that the support was only for teachers and schools near the centres (Fairhurst et al., 1999). Weindling et al. (1983) revealed that despite the unanimous support for teachers engaging in curriculum development at the TRC in the countries listed above, there are some limitations that hinder the intended outcomes. The main objective of all these case studies was to highlight the underlying idea that teacher centres would encourage and support professional development interactions.

\section{Teacher professional learning and development}

Darling-Hammond et al. (2017:2) conceptualise teacher professional learning "as a product of both externally provided and job-embedded activities that have the potential to increase teachers' knowledge and bring about change in their instructional practice in ways that support student learning". They argue that teacher learning involves both formal and informal learning activities. Given the complex nature of teacher professional learning and development, Avalos (2011) argues that teachers are the subjects and objects of learning and development, which requires their cognitive and emotional involvement. Similarly, Opfer and Pedder (2011) argue that teacher learning should be understood as a complex system rather than an event. For Opfer and Pedder (2011), professional learning should be viewed in the light of complexity theory, as they indicate that teacher learning is influenced by many factors such as the teacher, professional development activity and the school context. Opfer and Pedder (2011) note that professional learning may be influenced by the school context, the teacher's personality 
(attitude and beliefs) and the external stimulus provided by the learning activity. These interact with each other and combine with the dynamics of the individuals' social processes within their different contexts.

\section{CONCEPTUAL FRAMEWORK}

The conceptual framework used in this study was adapted from Harland and Kinder's (1997) model of nine possible outcomes of any professional development activity (Table 1). They describe material and provisionary outcomes and information outcomes (such as the distribution of new material or teaching resources) as third-order outcomes; new awareness, motivational and attitudinal outcomes, affective outcomes and institutional outcomes as second-order outcomes, and value congruence outcomes and knowledge and skills outcomes as first-order outcomes. While many professional development activities may achieve thirdlevel outcomes of distributing material and information, teachers may not learn any new knowledge or skills (first-level outcomes) which actually impact on their classroom practice.

Table 1: A hierarchy of professional development outcomes, adapted from Harland and Kinder (1997)

\begin{tabular}{|c|c|c|c|c|}
\hline \multirow{2}{*}{$\begin{array}{l}3^{\text {rd }} \text { order outcomes: } \\
2^{\text {nd }} \text { order outcomes: }\end{array}$} & \multirow{2}{*}{$\begin{array}{l}\text { Provisionary } \\
\text { Motivation }\end{array}$} & \multicolumn{2}{|c|}{ Information } & \multirow{2}{*}{$\begin{array}{l}\text { New a wareness } \\
\text { utional }\end{array}$} \\
\hline & & Affective & Inst & \\
\hline $1^{\text {st }}$ order outcomes: & \multicolumn{2}{|c|}{ Value congruence } & Knc & ledge and skills \\
\hline \multicolumn{5}{|c|}{ Impact on practice } \\
\hline
\end{tabular}

In this study, we were interested in what ways the activities offered at DTDCs achieved the first-order outcomes that contribute to learning of new knowledge and skills. Harland and Kinder (1997) suggest that such first-order outcomes are needed to bring about change in teachers' classroom practices that may then have a greater impact on teachers' learning. These outcomes are numerous, varied and complex, and they interact dynamically.

\section{RESEARCH METHODOLOGY}

\section{Research context}

This study used a qualitative design that incorporates case studies of seven DTDCs in KwaZulu-Natal. The case studies were undertaken by a number of researchers, including the authors and some Masters' students (Hlabisa, 2018; Mnguni, 2018; Shange LPP, 2018; Shange N, 2018; Thwala, 2018). Data presented in this study were generated through multiple data sources, including field visits to the centres, observation of the professional development activities, interviews with selected teachers and centre staff and document analysis of reports and attendance registers from workshops. The same data collection instruments were used in all the case studies. The hierarchy of in-service education and training (INSET) outcomes proposed by Harland and Kinder (1997) was used to frame the analysis of data. 
KwaZulu-Natal (KZN) is one of the nine provinces of South Africa and has 47 DTDCs (KZN DoE, 2014). The seven DTDCs purposively selected for this study were situated in four districts of KZN. The centres serve primary and secondary school educators, subject advisors, circuit managers, Department of Education (DoE) officials, learners from different schools and the community at large. The physical structures of the seven centres visited were found to be in good condition. The centres have access to electricity and water and are well fenced with burglar doors and windows. However, resources such as computers, available space provided and personnel at the centres vary.

\section{Participants and sampling}

Seven DTDCs were purposively selected as the case studies in this study. Interview data from 46 teachers and 17 centre personnel were generated. The teachers interviewed were those who were present at the DTDC when the researchers visited the centre; thus, this is not a representative sample of all teachers who may use the centre (Bertram \& Christiansen, 2014). Of the 46 teachers interviewed, 27 were female and 19 were male. Thirty-five were in the age range of 35 and 55 years, while 11 were aged between 25 and 30 years. The interviewed teachers taught at least two subject areas at two different grade levels. Thirty of the teachers interviewed had between 15 and 30 years of teaching experience, ten had between five and 14 years, while six had between one and four years. Of the 17 personnel interviewed, six were centre managers and two were librarians; other staff included a secretary, an ICT specialist, an IT technician, four administrative clerks, a science lab assistant and a receptionist. The selection criteria were based on a convenient sampling technique and participants' accessibility and willingness to participate in the study (Etikan et al., 2016; Wilson et al., 2016).

\section{Data collection methods}

Data were collected using semi-structured interviews, observations, document analysis and field notes. The interviews were audio-recorded, transcribed verbatim, coded and thematically analysed (Plunkett \& Dyson, 2011). Observations were conducted to ascertain the kind of resources available and the types of professional development activities offered at the DTDCs. The words of the participants, observations, document analysis and field notes informed our understanding of the role of the DTDCs and the impact they have on teacher learning. All ethical protocols were duly observed. Permission was granted by the University of KwaZuluNatal and the Department of Education to conduct the research and participants signed informed consent forms. Pseudonyms are used to ensure the anonymity of the participants and identity of the centres in this article (Creswell, 2013; Neumann, 2014).

\section{Brief description of the case studies}

Westheath centre is in a rural area with three permanent buildings of which two serve as workshop venues and one as a conference centre. There are two mobile structures, one of which is used as a science laboratory and the other as computer room with 24 computers with internet access. The centre has a centre manager, a library assistant, volunteer science laboratory assistant, Information Technology (IT) specialist and a cleaner. The second case, Peacedale centre, is also in a rural area. It has one big open-plan office for the centre manager, reception area for community engagement and space for circulars and other documents for schools. The centre has two rooms used for workshops and meetings, a science laboratory, library with almost-empty shelves and a computer room with 25 laptops with internet access and offices for the circuit manager and DoE officials when they visit the centre. The centre 
has a centre manager, a receptionist, ICT specialist, IT technician, a cleaner, gardener and security guard. There is a section at the centre used by University of South Africa (UNISA) to run their online programme and is monitored by an ICT clerk employed by UNISA. The third case, Sunshine centre, is in a remote rural area. It has one big hall used as a venue for workshops, seminars or meetings. A library and a computer room with 12 laptops with internet access. The centre also has eight offices for staff, one board room and four classrooms. Staff at the centre comprises the Centre Manager, an IT specialist, two cleaners, one gardener and two security guards. Ndlovu centre is in a semi-rural area and serves the as DTDC and as Municipal offices. The centre has four rooms: one is used as a meeting room, computer room with 26 computers, science laboratory and a library with few and out-dated books on its shelves. The centre comprises the centre manager, an administrative clerk, a librarian, two cleaners and one security guard. There is also a broadcasting facility for UNISA at the centre.

Lovedale DTDC is in a semi-rural area and has a permanent structure with relatively small spaces. The centre serves as a multipurpose and ecological centre where both primary and secondary school learners can engage actively with nature. The centre has one large office that is used as the media room with 15 computers but no internet access. The library simply comprises a few bookshelves with outdated books by the corner of the media room. The centre also has a Jika iMfundo resource bank "Nolwazi", which contains CAPS (the current school curriculum resources and past exam papers. Adjoining the media room is the centre manager's office. In addition to the centre manager, the centre has an administrator who is an intern, a cleaner and two security guards.

Jabavu DTDC is in an urban area and shares the premises with the Department of Art and Culture. The Centre has one big office for the two administrators, an adjoining office for the centre manager and four classrooms that are used as venues for workshops, meetings and three conference rooms. The centre has a science laboratory, a computer room with 24 computers with internet access and a library. The library was found to be in a state of disrepair due to rain, with many of the books, roof and floor being damaged. Personnel at the centre included the centre manager, two administrators, a librarian, a cleaner and gardener.

Funza DTDC is located in an urban area and has 24 air-conditioned classrooms that are used for meetings as well as workshops for subject teachers. There is also a large conference room, one fully fitted computer laboratory with 25 functional computers but without internet. There are also two halls in which one operates as a boardroom and the other as a conference room. There is a mobile library bus that distributes books to the schools that do not have a library for a specified loan period and collects them again. There is also a processing centre that is used to process the books received from Eduction Library Information and Technology Services (ELITS) before they are dispatched to schools. There is a centre manager, a receptionist, admin officer, processing centre coordinator, a handyman, a cleaner and two security guards.

Table 2: Summary of the resources at the District Teacher Development Centres

\begin{tabular}{lccccccc}
\hline Centre Name & Westheath & Peacedale Sunshine & Lovedale & Ndlovu & Jabavu & Fuanz \\
\hline Nature of District & Rural & Rural & $\begin{array}{c}\text { Remote } \\
\text { Rural }\end{array}$ & Semi-Rural & Semi-rural & Urban & Urban \\
\hline No. of Staff & 5 & 5 & 7 & 5 & 5 & 6 & 8 \\
\hline No. of Classrooms & 3 & 4 & 4 & 3 & 3 & 4 & 24 \\
\hline
\end{tabular}




\begin{tabular}{|c|c|c|c|c|c|c|c|}
\hline Centre Name & Westheath & Peacedale & Sunshine & Lovedale & Ndlovu & Jabavu & Fuanz \\
\hline No. of Offices & & & 8 & & & & \\
\hline No. of Computers & 24 & 25 & 12 & 20 & 26 & 24 & 25 \\
\hline $\begin{array}{l}\text { Conference Hall/ } \\
\text { Room }\end{array}$ & 1 & & 1 & 0 & 1 & 3 & 1 \\
\hline $\begin{array}{l}\text { No of Science } \\
\text { Laboratories }\end{array}$ & 1 & 1 & 0 & 0 & 1 & 1 & 0 \\
\hline No of Libraries & 1 & 1 & 1 & 1 & 1 & 1 & 1 \\
\hline $\begin{array}{l}\text { Functioning Level } \\
\text { of Library }\end{array}$ & Not used & Not used & Not used & Not used & Not used & Not used & $\begin{array}{l}\text { Not } \\
\text { used }\end{array}$ \\
\hline
\end{tabular}

\section{FINDINGS}

This section presents the findings of the study and discusses participants' understanding of the purpose of DTDCs, activities offered, available resources and how these resources support teachers' learning.

\section{Participants' understanding of the purpose of the DTDC}

According to interviewed teachers, the overwhelming purpose of the DTDCs is as a "venue for teacher meetings", to help teachers from different schools in the same area to come together and form clusters. Some teachers viewed the DTDCs as "a venue where moderation and workshops are conducted for teachers by district education officials and subject advisers". Trevone, a Natural Sciences teacher who is also a cluster coordinator believed the centre to be for administrative purposes. For example, when the DoE needs to conduct a headcount of teachers for statistical purposes, the officials would call teachers from neighbouring schools to assemble at the venue. Chikoko revealed, "I go there mainly for attending workshops and to find out information on cross transfers from the administrative office".

Similarly, Lungy, a high school Mathematics teacher, stated that: "It's a teacher resource centre, I would say, and also a venue where teachers would meet to discuss issues affecting them in their careers". Sizwe, a deputy principal of a local high school, agreed with Trevone that the centre is a venue where teachers meet for workshops and for meetings which are held by the South African Democratic Teachers Union (SADTU). He also maintained that the centre plays a remarkable role through the resources it offers, which are not present in schools, such as the conference room that accommodates more than 30 teachers. Centre managers shared similar views with most teachers. A typical remark includes: "The centre is about capacitating teachers in different subjects. The subject advisers and the teachers from different schools come here for workshops on different learning areas." Nicole, a centre manager also explained that the DTDC provides resources and supports teachers, guides professional learning committees and runs workshops after performing a needs analysis as well as providing a venue for meetings.

Teachers and centre managers view DTDCs as venues for meetings and workshops for teachers in different learning areas to carry out Curriculum and Assessment Policy Statement (CAPS) and School-Based Assessment (SBA) moderation. To some degree these views comply with the ISPFTED policy, which states that: 
DTDCs are to serve as local support sites for teachers, sites from which curriculum support staff can operate sites where teachers can access shared resources, sites of delivery for continuing professional development courses and as meeting points for teacher professional learning communities (DBE \& DHET, 2011:13).

It was evident from the study that participants simply view the DTDC as a venue for meeting and workshop purposes only. The finding reveals that participants in the study did not understand the objectives of the "Plan" policy.

\section{Professional development activities offered at the centres}

Evidence from the interviews and observations indicates that activities offered at the centres include moderation of school-based assessments, content workshops, curriculum coverage/ orientation workshops, computer literacy training and cluster meetings. Participants from the Sunshine and Funza centres also mentioned computer training on Microsoft Office (Word, Excel, PowerPoint), how to create a database and email was offered, and that teachers were awarded certificates. Some teachers mentioned that attending computer literacy workshops has improved their computer literacy. They indicated that they now know how to type their own question papers at school. This reveals that they learned new skills that can be attributed to learning at the centres.

In the collection of documents, we perused, we found attendance registers of computer workshops conducted for teachers in 2016. Moderation appeared to be the main professional development activity offered at the centres. Participants stated that moderation focuses on exam questions and marks, question papers, marking of scripts and discussion of previous exams question papers. Most participants had a positive attitude towards these moderation exercises, stating that it provides them with an opportunity to discuss the challenges they experience in setting examination questions and marking scripts. Simangele, a Grade 10 English and History teacher, explained:

As you know KZN is so big, this centre helps us to get a nearby place with resources that make our work easier in terms of teaching. For example, subject advisors come to the centres for us and give us information that we need. They also check our marking; how do we mark. If we have meetings, as teachers we come here and discuss a way forward also get enough information. We are also helping each other as teachers.

The teachers indicated that they attend moderation workshops at the centres organised by subject advisers to check their level of compliance with the Annual Teaching Plan (ATP). Majeyi stated that:

We are checked if we are behind with curriculum and we come with strategies on how we are going to fill those gaps because if you are behind there is an annual teaching plan where you state the date when that section of work will be done because the Department has got the exact date for the completion of each lesson or topic.

In addition, interviewed teachers stated that they were provided a CD to download CAPS documents, annual teaching plans, work programmes, past years question papers, pamphlets and study guides at moderation workshops.

A group of isiZulu subject teachers use Sunshine DTDC as a venue to participate collaboratively in activities that encourage them to learn from one another. The three interviewed teachers belong to a Professional Learning Community established by teachers 
after a moderation workshop and saw the need to continuously meet out-of-moderation. The teachers indicated that the centre provided them with a central venue since they are from different schools.

One of the participants, Chonco, mentioned, "being part of the collaborating group has improved my quality of teaching and I produce good results in my matric class". He indicated that he was not confident in teaching poetry but coming together as isiZulu teachers and engaging in poetry collaboratively has made his teaching much easier: "participating in this activity has uncovered new knowledge and understanding". This view is consistent with policy that states that DTDCs serve as a meeting venue for PLCs, which is the only learning activities driven by teachers. The use of collaboration amongst teachers present an ideal opportunity to improve teachers' growth as well as teaching and learning practice (Steyn, 2014).

\section{Learning from activities at the centre}

Several participants indicated that they had gained new knowledge and skills because of moderation and content-related workshops. Typical comments include "After sharing our experiences like content challenges, methods of tackling certain topics, I just feel ready to respond to any questions my learners might have". Other teachers shared similar sentiments.

After attending these content workshops, one comes out bold and confident about teaching the subject and you see one feels bad to miss any of these workshops.

Coming back from the content workshop enables me to give confident feedback to my learners; you see I am in the position of presenting a new and fresh perspective.

Vusi also revealed:

I used to be very frustrated when my learners fail my subject or when they score very low marks. Memo discussion workshops have taught me that some answers might be expressed slightly different from the memorandum and be more accommodative of the answers conveying the similar idea.

Jele noted,

Yes, I have learnt a new way of marking learner's assessment tasks ... for example all Grade 12 isiZulu teachers in my cluster bring in a sample of marked learners' scripts and exchange in ensuring standardisation and consistency in teachers' marking.

Teachers Mabheleni, Malwande, Philani, Pranesh, Kele, Benzile and Majeyi regarded themselves as lifelong learners and said that they learn a lot at the centres that keep them up to date with all the curriculum changes. These responses are confirmation that the DTDC programmes have produced certain positive feelings and motivation.

\section{Resources at the centres}

Most of the centres have a library, computers, a science laboratory, photocopying machines and so on. However, many of these resources were not functional. Computers are not used owing to a lack of trained personnel and internet access, and many of the libraries stock outdated and unrelated textbooks. Several teachers said that they had never used the library or the computers at the centres except for those at Sunshine and Funza centres. We also found that centres with laboratories find it challenging to use the equipment due to a lack of personnel. Despite internet facilities at some of the centres, they lacked trained personnel to 
run computer literacy classes for teachers. We argue that without the relevant personnel at the centres, no professional development activities can be conducted effectively.

Ayanda, a Grade 7 Natural Sciences teacher at Peacedale Centre, lamented: "As much as I like to visit the centre and use the science laboratory, unfortunately, I cannot ... ever since (Nicky) the laboratory assistant left there has been no replacement and therefore when teachers go there, there is no one to assist them." Ayanda also mentioned that attempts to raise the issue with the centre manager had been futile. Ceasa, a teacher, affirmed, "there is no internet here and the books are old and unrelated". Such experiences thus become a setback for the teachers and policymakers in creating better learning experiences for holistic school development. Sithe, a school principal, said:

I think there is a library and computers here, but I don't know much. We only come here for workshops and meetings. I think it is an information problem.

Ngcobo, a Life Orientation teacher, asserted:

I know there are computers and library here at the centre, but I was never told by the manager, my school, Department officials or even the subject advisers that the resources at the centre are meant for us.

However, Susana (a science lab assistant) had a different perspective. She believes that some teachers are aware of the resources at the centre but hardly use them. Jotham (centre librarian) at Lovedale corroborated Susana's view, stating that, "teachers hardly visit the library at the centre despite the department supplying instructional materials".

Sindy and Zuthole, both centre managers, confirmed that not all teachers who visit the centre know about available resources. Sindy thought that some teachers could be reluctant to use the resources in the science laboratory because there is no one to assist them. She explained:

Previously we had two qualified assistants but were here on a two-year contract which was never renewed. There has not been any replacement for them. I'm the only one who assists wherever possible.

Similarly, observation revealed the science laboratory materials were insufficient and the learning space in the science lab was not in line with the specified standards.

\section{DISCUSSION}

\section{Participants' understanding of the purpose of the DTDC}

The vision of the DTDCs as espoused by the ISPFTED is clearly stipulated that DTDCs are to serve as support sites for teachers, access shared resources, delivery for continuing professional development courses and as meeting points for teacher professional learning communities (DBE \& DHET, 2011). Our findings demonstrate that participants largely understood DTDCs as venues for meetings and workshops called by the Department of Education. This limited vision of the DTDCs by participants means that most teachers do not take ownership of these resources to support their own professional development and learning. They are waiting to be called to attend workshops and meetings at the Centres. 


\section{Professional development activities offered at the centres}

One of the important components of any professional development activity is that it should be related to teachers' specific learning needs (DBE \& DHET, 2011). The DTDCs in this study did not provide a selection of professional activities that would enable teachers to learn new pedagogic content knowledge or content knowledge that was not directly linked to the implementation of state policies. Moderation workshops are one of the main professional development activities offered at the centres. However, we argue that the activities of marking learner scripts, setting question papers and revising past exams papers are focused on achieving smooth implementation of state policies, and are not necessarily activities that lead to teacher learning. Moderation also plays the role of monitoring teacher accountability and thus could reflect as a managerial professionalism discourse (Day \& Sachs, 2004). Hence, there was no evidence of professional development that supports teachers' specific strengths and addressed their specific needs, and that was not linked to compliance with policy directives (Kennedy, 2014). Thus, the vision of the DTDC as being a place where a "variety of modes of study and support" (DBE \& DHET, 2011:8) are offered is at present not being implemented at these centres. Avalos (2011) argues that the core of professional development endeavours is about teachers learning how to learn and transform their knowledge into practice for the benefit of their students' growth. This transformation of knowledge that was driven by teachers was not apparent in our case studies. Rather, we argue that professional development activities offered at the DTDCs are driven by the provincial Department of Education to ensure that teachers understand and comply with the assessment and curriculum policies.

\section{Learning from activities at the centre}

In this study, participants at the centres we studied have specific ways of working together that are related to the values and principles of the profession. The first important observation in our study is that there was only one example of a group of teachers who used the DTDC as a venue for their professional learning community. This was a group of isiZulu teachers who met at the centre on their own volition. Evidence from our study reveals that teacher collaboration took place outside of the workshop. This is an indication that these teachers have developed some levels of trust to support each other in their profession. In addition, collaborative learning allows teachers chances to progress and be developed well in their teaching (Bantwini, 2018).

A second important observation was that some teachers were equipped with computerrelated skills and provided the resources to browse the internet for information, download material to use when teaching as well as prepare computer-generated lesson plans. This statement confirms that activities at DTDCs support some teachers to develop computer skills. The DTDC therefore fulfils its role to support teacher learning in some capacity and meets the requirements of DTDCs, as clearly stated in the policy (DBE \& DHET, 2011). The third observation was that many of the participants noted that they learnt from the moderation of school-based assessment about appropriate marking standards and setting of exams questions according to the curriculum guidelines. This indicates that Harland and Kinder's (1997) first-order outcomes were achieved, which relates to acquiring new knowledge and skills. However, the focus on moderation of assessment and on setting exam questions indicates a strong focus on managerial professionalism, which is driven by the state for the purposes of implementing state policies (Day \& Sachs, 2004). Teachers also received new information about assessment guidelines and curriculum planning and materials. This new information and materials received such as CAPS documents, annual teaching plans and work 
programmes, indicates that Harland and Kinder's (1997) third-order outcomes were achieved. It was not, however, possible to conclude that the first-level outcomes of learning how to moderate and set school-based assessment tasks lead to changed pedagogic practices.

\section{Resources at the centres}

Evidence from the findings reveals resources for learning, including library, laboratory, computers and internet access. We noted that resources were seldom utilised and science equipment often sits in locked cupboards gathering dust and rust. Library shelves are often half empty and books are outdated. The findings in this study suggested that teachers did not access nor share resources at the centres. Despite the policy statement regarding the DTDCs as a site for teachers to access shared resources, the study found that this was not the case with these centres. We argue that a lack of resources is not in accordance with specified standards for the DTDCs Norms and Standards (DBE, 2015) which stipulates that DTDCs should be equipped with relevant resources to support teaching and learning.

Levin (2010) points out that lack of attention to adequate implementation is a major flaw in policy process. He highlights two elements that are critical to successful implementation: the importance of engaging those who must make the change in the process of learning and improvement, and the need for "enough skilled people to provide ongoing support". We recommend that to ensure a coherent system that supports teachers, teachers should be made aware of the purpose and function of the centres, more personnel should be provided to improve the cohesion and coordination of professional development activities at the centres and resources should be updated and maintained. In addition, setting up of DTDCs and aligning resources to current education practice should be developed and reviewed with active involvement of teachers and personnel who are themselves professionals in the field.

\section{CONCLUSION}

The policy on DTDC structures and its required procedures and purposes are clearly stated. This study set out to answer the questions outlined in the introduction: What kind of professional development activities are delivered at the centres? How are the professional learning communities organised and monitored? And, are there enough personnel to run the DTDCs? The study discovered that DTDCs only offer professional development activities that are aimed at the implementation of the curriculum and assessment policies. Very few teachers initiated PLCs which met at the centres. The study also found that the centres were limited in their capacity by lack of trained personnel. Most teachers visit the centres only to attend meetings and curriculum workshops. We conclude that the DTDCs in this study do not significantly support teachers' learning and development beyond the workshops offered for the implementation of state policies. The DTDCs in our case studies provide venues for meetings and workshops but these meetings do not provide wide-ranging professional development activities. The centres also provide access to resources that are often inadequate, nonfunctional and barely utilised. We argue that without relevant resources at the centres, it is impossible for them to offer any professional development activities. This study concludes that the expectations of the policy that the centres should support teachers' learning have not been realised holistically. 


\section{REFERENCES}

Avalos, B. 2011. Teacher professional development in teaching and teacher education over ten years. Teaching and Teacher Education, 27(1): 10-20. https://doi.org/10.1016/j. tate.2010.08.007.

Bayar, A. 2014. The components of effective professional development activities in terms of teachers' perspective. International Online Journal of Educational Sciences, 6(2): 319-27. https://doi.org/10.15345/iojes.2014.02.006.

Bantwini, B.D. 2018. District officials' perspectives regarding factors that impede the attainment of quality basic education in a province in South Africa. Education, 3-13.

Bantwini, B.D. 2012. Primary school science teachers' perspectives regarding their professional development: Implications for school districts in South Africa. Professional Development in Education, 38(4): 517-532. https://doi.org/10.1080/03004279.2018.1526200. https://doi.org/ 10.1080/19415257.2011.637224.

Bautista, A., Cañadas, M.C. Brizuela, M.B. \& Schliemann, A.D. 2015. Examining how teachers use graphs to teach mathematics in a professional development program. Journal of Education and Training Studies, 3(2): 91-106. https://doi.org/10.11114/jets.v3i2.676.

Bautista, A., Wong, J. \& Gopinathan, S. 2015. Teacher professional development in Singapore: Depicting the landscape. Psychology, Society and Education, 7(3): 311-326. https://doi. org/10.25115/psye.v7i3.523.

Bertram, C. \& Christiansen, I. 2014. Understanding research: An introduction to reading research. Pretoria: Van Schaik.

Bertram, C. 2011. What does research say about teacher learning and teacher knowledge? Implications for professional development in South Africa. Journal of Education, 52: 3-26.

Borko, H., Jacobs, J. \& Koellner, K. 2010. Contemporary approaches to teacher professional development. In P. Peterson, E. Baker, B. McGaw (Eds.). International Encyclopaedia of Education. Oxford: Elsevier, 548-556. https://doi.org/10.1016/B978-0-08-044894-7.00654-0.

Cohen, D.K. 2011. Teaching and its predicaments. Cambridge: Harvard University Press. https://doi.org/10.4159/harvard.9780674062788.

Creswell, J.W. 2013. Qualitative inquiry and research design: Choosing among five approaches, 3rd ed. Thousand Oaks, CA: Sage.

Darling-Hammong, L., Hyler, M.E. \& Gardner, M. 2017. Effective teacher professional development. Palo Alto, CA: Learning Policy Institute.

Day, C. \& Sachs, J. 2004. Professionalism, performativity and empowerment: Discourses in the politics, policies and purposes of continuing professional development. In C. Day \& J. Sachs (Eds.). International handbook on the continuing professional development of teachers. UK: Open University Press, 3-32.

Department of Basic Education (DBE) 2015. Action plan to 2019: Towards the realisation of schooling 2030. Taking forward South Africa's National Development Plan 2030. Pretoria.

Department of Basic Education and Department of Higher Education \& Training (DBE \& DHET) 2011. Integrated strategic planning framework for teacher education and development in South Africa, 2011-2025, Pretoria. 
Department of Education KwaZulu-Natal Province 2014. Teacher centres Kwa-Zulu Natal. http://www.digitalclassroom.co.za/digitalclassroom/kwazulu-natal [Accessed October 2018].

Etikan, I., Musa, S.A. \& Alkassim, R.S. 2016. Comparison of convenience sampling and purposive sampling. American Journal of Theoretical and Applied Statistics, 5(1): 1-4. https:// doi.org/10.11648/j.ajtas.20160501.11.

Fairhurst, G., William, G., Pankaj, J., Khatete, D., Knamiller, G., Welford, G. \& Wiegand, P. 1999. The effectiveness of teacher resource centre strategy. Education research paper. Full Report. Department for International Development.

Giordano, E.A. 2008. School clusters and teacher resource centres. Paris: United Nations Search.

Harland, J. \& Kinder, K. 1997. Teachers' continuing professional development: Framing a model of outcomes. British Journal of In-Service Education, 23(1): 71-83. https://doi. org/10.1080/13674589700200005.

Higgins, J. \& Parsons, R. 2011. Professional learning opportunities in the classroom: Implications for scaling up system level professional development in mathematics. Mathematics Teacher Education and Development, 13(1): 54-76.

Hlabisa, S. 2018. Exploring the role of a District Teacher Development Centre as a space to support teachers' professional learning. A case study of Ngotsha DTCDC Unpublished MEd dissertation, University of KwaZulu-Natal, Pietermaritzburg.

Jita, L.C. \& Mokhele, M. 2014. When teacher clusters work: Selected experiences of South African teachers with the cluster approach to professional development. South African Journal of Education, 34(2): 1-15. https://doi.org/10.15700/201412071132.

Kennedy, A. 2014. Understanding professional development: The need for theory to impact on policy and practice. Professional Development in Education, 40(5): 688-697. https://doi.or g/10.1080/19415257.2014.955122.

Klieger, A. \& Oster-Levinz, A. 2015. The influence of teacher education on mentor teachers' role perception in professional development schools. Journal of Education for Teaching International Research and Pedagogy, 41(2): 115-127. https://doi.org/10.1080/02607476.2 015.1010873.

Levin, B. 2010. Governments and education reform: Some lessons from the past 50 years. Journal of Education Policy, 25(6): 739-747. https://doi.org/10.1080/02680939.2010.523793.

Luneta, K. 2012. Designing continuous professional development programmes for teachers: A literature review. Africa Education Review, 9(2): 360-379. https://doi.org/10.1080/1814662 7.2012.722395.

Maskit, D. 2011. Teachers' attitudes toward pedagogical changes during various stages of professional development. Teaching and Teacher Education, 27(5): 851-860. https://doi. org/10.1016/j.tate.2011.01.009.

Mnguni, N. 2018. Exploring the role of Peacedale District Teacher Development Centre in KZN in supporting teachers' professional learning Unpublished MEd dissertation. Pietermaritzburg: University of KwaZulu-Natal.

Mosha, M.A. 2015. The role of teachers' resource centres in teachers' professional development and enhancing primary education in Zanzibar. Journal of Education and Practice, 6(8): 44-61. 
Neumann, W.L. 2014. Social research methods: Qualitative and quantitative approaches $\left(7^{\text {th }}\right.$ ed.). London: Pearson Education Limited.

Opfer, V.D. \& Pedder, D. 2011. Conceptualising teacher professional learning. Review of Educational Research, 81(3): 376-407. https://doi.org/10.3102/0034654311413609.

Plunkett, M. \& Dyson, M. 2011. Becoming a teacher and staying one: Examining the complex ecologies associated with educating and retaining new teachers in rural Australia. Australia Journal of Teacher Education, 36(1): 32-47. https://doi.org/10.14221/ajte.2011v36n1.3.

Shange, L.P.P. 2018. Exploring the role of a District Teacher Development Centre in supporting teachers' professional learning Unpublished MEd dissertation. Pietermaritzburg: University of KwaZulu-Natal.

Shange, N. 2018. Exploring the role of the Sunshine District Teacher Development Centre in KZN in supporting teachers' professional learning. Unpublished Med dissertation. Pietermaritzburg: University of KwaZulu-Natal.

Steyn, G.M. 2014. Holding the reigns to demonstrate the key features of a teacher learning community in a South African School. Mediterranean Journal of Social Sciences, 5(23): 1331 1339. https://doi.org/10.5901/mjss.2014.v5n23p1331.

Thwala, N.P.N. 2019. Exploring how a District Teacher Development Centre supports teachers' professional learning. A case study in Phumelela District. Unpublished MEd dissertation. Pietermaritzburg: University of KwaZulu-Natal.

Van den Bergh, L., Ros, A. \& Beijaard, D. 2015. Teacher learning in the context of a continuing professional development programme: A case study. Teaching and Teacher Education, 47: 142-150. https://doi.org/10.1016/j.tate.2015.01.002.

Van Der Berg, S., Burger, C., Burger, R., De Vos, M., Du Rand, G., Gustafsson, M., Moses, E., Shepherd, D., Spaull, N., Taylor, S., Van Broekhuizen, H., \& Von Fintel, D. 2011. Low quality education as a poverty trap. A Working Paper of the Department of Economics and the Bureau for Economic Research at the University of Stellenbosch. https://doi.org/10.2139/ ssrn.2973766.

Weindling, D., Reid, M.I., \& Davis, P. 1983. Teachers'centres: A focus for in-service education? Schools Council Working Paper 74, London: Methuen Educational.

Wilson, A.L. Greenacre, L., Pignata, S. \& Winefield, A. 2016. Challenging the notion of the transition year: the experiences of rural and urban tertiary students. International Journal of Educational Research, 79: 21-30. https://doi.org/10.1016/j.ijer.2016.06.002. 